\title{
クエン酸第二鉄の血液透析患者における有用性
}

\author{
菅 沼 信 也 ${ }^{1}$ 阿 部 達 弥 ${ }^{2}$ 西 澤 喬 光 $^{2}$ 正木 一 郎 ${ }^{2}$ \\ 1菅沼会婜内科クリニック世田谷人工透析内科 \\ 2菅沼会腎内科クリニック世田谷臨床工学部
}

キーワード：クエン酸第二鉄，リン吸着薬，代謝性アシドーシス，腎性貧血，血液透析

〈要旨〉

【目的】当院では代謝性アシドーシス補正効果の高いクエン酸含有無酢酸透析液を用いているが, 一部の患者でアシ ドーシス補正が十分でない，そこで，血清重炭酸濃度上昇作用を有するリン吸着薬クエン酸第二鉄製剤（FC）の影 響を後乃向きに調査した.【対象と方法】当院通院外来維持透析患者で既存薬から FC に変更または追加した 72 名 を対象に, FC 投与開始前, 投与 3 力月後の CKD-MBD, 貧血指標と週中日の透析前血清重炭酸濃度を比較した.

【結果】透析前重炭酸濃度は, 全例では FC 投与後変化はなかったが, $22 \mathrm{mEq} / \mathrm{L}$ 未満の患者 30 例では有意に上昇し た. FC 投与に伴い FC 由来の鉄が吸収され, TSAT $20 \%$ 未満かつ血清フェリチン值 $100 \mathrm{ng} / \mathrm{mL}$ 未満の絶対的鉄欠乏 の患者が著減し, ESA 投与量が有意に減少した.【結語】 FC はリン吸着および鉄補充に伴う貧血改善作用に加え代 謝性アシドーシス補正作用を有し, 特に異所性石灰化等のリスクとなる代謝性アシドーシス患者において有用なリ ン吸着薬になり得る。

\section{Usefulness of ferric citrate in hemodialysis patients}

\author{
Shinya Suganuma', Tatsuya Abe ${ }^{2}$, Takamitsu Nishizawa $^{2}$, Ichiro Masaki² \\ ${ }^{1}$ Department of Artificial Dialysis, Kidney Clinic Setagaya \\ ${ }^{2}$ Department of Clinical Engineering, Kidney Clinic Setagaya
}

Keywords: ferric citrate, phosphate binder, metabolic acidosis, renal anemia, hemodialysis $\langle$ Abstract〉

【Aim】 Hemodialysis (HD) using citrate-containing acetate-free dialysate had a strong ameliorating effect on metabolic acidosis in our clinic, but metabolic acidosis was not sufficiently improved in some HD patients. Ferric citrate (FC) is an iron-containing phosphate binder, and was reported to increase serum bicarbonate concentrations. The acidosis-ameliorating effect of FC was retrospectively investigated.【Patients and Methods】 Chronic kidney disease-mineral and bone disorder parameters, the anemia-related index, and the pre-dialysis serum bicarbonate concentration were compared in 72 outpatient maintenance HD patients who were changed from existing phosphate binders to FC or had FC added to their existing phosphate binders.【Results】 The data obtained before and 3 months after the initiation of FC treatment were compared. Although the mean pre-dialysis bicarbonate concentration was not affected by the administration of FC in all patients, it increased significantly in 30 patients with pre-dialysis bicarbonate concentrations of $<22 \mathrm{mEq} / \mathrm{L}$. The absorption of $\mathrm{FC}$-derived iron led to the number of patients with absolute iron deficiency (defined as a transferrin saturation value of $<20 \%$ and a serum ferritin level of $<100 \mathrm{ng} / \mathrm{mL}$ ) markedly decreasing, and the mean erythropoiesis-stimulating agent dose decreased significantly.【Conclusion】 FC is a phosphate binder, which ameliorates renal anemia and metabolic acidosis. It is particularly useful for HD patients with metabolic acidosis, who are at risk of ectopic calcification.

菅沼 信也 医療法人社団菅沼会腎内科クリニック世田谷％ 157-0062 東京都世田谷区南烏山 4-21-14

Shinya Suganuma Tel: 03-5969-4976 Fax：03-5969-4970 E-mail: s.suganuma@jinnaika.com

〔受付日：2017 年 12 月 1 日, 受理日：2018 年 9 月 21 日〕 


\section{緒言}

透析患者は，腎機能の低下，廃絶に伴い，多くの患 者が代謝性アシドーシスとなるため, 透析療法によ り, 水, 電解質の補正とともにアシドーシスの補正が 行われる. 当院では, セントラル透析液供給システム (central dialysis fluid delivery system: CDDS) で, 高い代謝性アシドーシス改善効果が報告 ${ }^{1)}$ されている クエン酸含有無酢酸透析液, 製品名: カーボスター ${ }^{\circledR}$. $\mathrm{P}$ 透析剂（Carbostar $\left.{ }^{\circledR}: \mathrm{CAB}\right)$ を用いた血液透析を施 行している.しかし，CDDSでは，すべての患者に同 一組成の透析液が用いられるため, 一部の患者では CAB を用いても十分なアシドーシス補正がなされて いない.

2014 年 5 月, $\mathrm{Ca}$ 非含有リン吸着薬として, クエン 酸第二鉄製剂，製品名：リオナ ${ }^{\circledR}$ 錠 $250 \mathrm{mg}$ (ferric citrate：FC）が発売された. Yokoyamaらは, FCは 消化管内でリンを吸着してリン低下作用を示すのに加 え, 有効成分の 3 価鉄が一部吸収され，鉄補充に伴う 腎性貧血改善作用や有効成分のクエン酸により血清重 炭酸濃度が上昇することを報告している ${ }^{2,3)}$.

そこで, FCのリン吸着作用，鉄代謝および腎性貧 血に及ぼす影響に加え, $\mathrm{pH}$, 透析前重炭酸濃度に及ぼ す影響を後ろ向きに検討した。

\section{I. 対 象}

対象は, 当院外来維持血液透析患者のうち, 以下の 基準を満たす患者 72 例である.

1） $\mathrm{FC}$ 服用開始時 20 歳以上，90 歳以下.

2）透析導入後 6 か月以上経過している.

3） FCを 3 か月以上継続服用している.

4） FC 以外の経口鉄含有製剂を服用していない.

\section{II. 方 法}

\section{1. 評価項目}

$\mathrm{FC}$ 処方開始前および 3 か月後の血清リン值，補正 $\mathrm{Ca}$ 值, 日本透析医学会 慢性腎臓病に伴う骨・ミネラ ル代謝異常の診療ガイドライン（以下, CKD-MBD 診 療ガイドライン $)^{3)}$ の達成率（リンおよび補正 $\mathrm{Ca}$ の同 時達成率), 鉄代謝指標として, トランスフェリン飽和 度（TSAT）および血清フェリチン値，貧血関連指標 として赤血球数 (RBC), 平均赤血球へモグロビン量 (mean corpuscular hemoglobin：MCH) およびへモグ
ロビン濃度 $(\mathrm{Hb})$, ダルベポエチン アルファ（Darbepoetin Alfa: DA) 換算 ESA (erythropoiesis stimulating agent) 投与量（エポエチン ベータ：DA：エポエ チン ベータ ペゴル = 300:1 : 1 とした週あたりの総 量をDA 換算で算出), ERI (erythropoietin resistance index, DA 換算 $\mu \mathrm{g}$ を $\mathrm{Hb}$ で除した值), 静注鉄剤（含 糖酸化鉄注射液, 製品名：フェジン ${ }^{\circledR}$ 静注 $40 \mathrm{mg}$ ）の 処方患者数および投与量に加え, 中 1 日の透析前 $\mathrm{pH}$ および重炭酸濃度を後ろ向きに調査した。

なお，当院では施設基準として，補正 $\mathrm{Ca}$ 值の管理 目標值を 8.0〜9.5 mg/dL に設定しているため, CKDMBD 診療ガイドライン達成率は, ガイドライン基準 の補正 $\mathrm{Ca}$ 值 $8.4 \sim 10.0 \mathrm{mg} / \mathrm{dL}$ と $8.0 \sim 9.5 \mathrm{mg} / \mathrm{dL}$ の両 方について算出した.

解析は, 72 例全例で実施するとともに, FC 処方開 始前の透析前重炭酸濃度 (中 1 日採血) が $22 \mathrm{mEq} / \mathrm{L}$ 未満であった 30 例の患者 (以下, 代謝性アシドーシス 患者）を抽出し，同様の解析を行った.

\section{2. 統計処理}

臨床検査值の経時変化は, 対応のある $\mathrm{t}$-検定を行っ た. ESA および静注鉄剂の投与量の変化は, Wilcoxson 符合付順位和検定を行った. 静注鉄剤使用患者数 の変化は, Fisher の正確確率検定を行った. いずれの 検定も $p<0.05$ を有意水準とし, 表記は平均值 $\pm \mathrm{SD}$ と した。

\section{3. 倫理的配慮}

本研究は, 腎内科クリニック世田谷倫理委員会の承 認を得ており (承認番号 0009), すべての患者からデー 夕使用の同意を得て実施した.

\section{III. 結 果}

\section{1. 患者背景}

基準を満たした 72 例全例，およびこのうち代謝性ア シドーシス患者 30 例の患者背景を表 1 に示す。代謝性 アシドーシス患者 30 例の患者背景は年齢, 透析前 $\mathrm{pH}$ および重炭酸濃度を除き, 全例 72 例と同様の分布で あった。

鉄マーカーについては, TSAT 20\%未満かつ血清 フェリチン值 $100 \mathrm{ng} / \mathrm{mL}$ の絶対的鉄欠乏の患者は 72 例中 47 例 $(65.3 \%)$, 代謝性アシドーシス患者 30 例中 16 例 $(53.3 \%)$ であった。

$\mathrm{FC}$ は, FC 投与開始前のリン吸着薬に追加あるいは 一部切替えで投与した. 開始時用量は 250〜 750 mg/ 日で，期間中適宜増減した。 
表 1 Baseline characteristics of the patients.

\begin{tabular}{|c|c|c|}
\hline & All patients $(\mathrm{n}=72)$ & Acidic patients $(\mathrm{n}=30)$ \\
\hline Male/Female & $46 / 6(63.9 \% / 36.1 \%)$ & $19 / 11(63.3 \% / 36.7 \%)$ \\
\hline Age（years） & $68.1 \pm 13.1 \quad(40 \sim 90)$ & $61.1 \pm 11.6 \quad(43 \sim 85)$ \\
\hline HD duration (years) & $3.9 \pm 3.9(0 \sim 19)$ & $3.8 \pm 3.8(0 \sim 13)$ \\
\hline $\mathrm{DM} /$ non-DM & $32 / 40(44.4 \% / 55.6 \%)$ & $13 / 17(43.3 \% / 56.7 \%)$ \\
\hline DW (kg) & $60.3 \pm 12.9$ & $61.1 \pm 11.6$ \\
\hline Modality (HD/on-line HDF/I-HDF) & $28 / 25 / 19$ & $10 / 8 / 12$ \\
\hline $\mathrm{Q}_{\mathrm{B}}(\mathrm{mL} / \mathrm{min})$ & $293.2 \pm 76.9$ & $294.5 \pm 86.5$ \\
\hline HD time $(\min )$ & $267.6 \pm 33.0$ & $272.6 \pm 34.0$ \\
\hline Phosphate (mg/dL) & $5.31 \pm 0.99$ & $5.39 \pm 1.00$ \\
\hline Corrected $\mathrm{Ca}(\mathrm{mg} / \mathrm{dL})$ & $8.73 \pm 0.49$ & $8.60 \pm 0.57$ \\
\hline intact PTH $(\mathrm{pg} / \mathrm{mL})$ & $235.6 \pm 197.4$ & $249.5 \pm 256.2$ \\
\hline pre-HD pH & $7.42 \pm 0.04$ & $7.40 \pm 0.03$ \\
\hline pre-HD $\mathrm{HCO}_{3}^{-}(\mathrm{mEq} / \mathrm{L})$ & $22.70 \pm 2.71$ & $20.17 \pm 2.38$ \\
\hline TSAT $(\%)$ & $17.14 \pm 11.31$ & $18.81 \pm 13.01$ \\
\hline Ferritin $(\mathrm{ng} / \mathrm{mL})$ & $55.2 \pm 46.8$ & $55.3 \pm 50.4$ \\
\hline $\operatorname{RBC}\left(10^{4} / \mu \mathrm{L}\right)$ & $354.7 \pm 47.7$ & $358.9 \pm 52.2$ \\
\hline $\mathrm{MCH}(\mathrm{pg})$ & $28.85 \pm 2.82$ & $29.05 \pm 2.86$ \\
\hline $\mathrm{Hb}(\mathrm{g} / \mathrm{dL})$ & $10.11 \pm 0.92$ & $10.34 \pm 0.93$ \\
\hline ESA dose (DA conversion, $\mu \mathrm{g} /$ week) & $29.8 \pm 34.1$ & $34.9 \pm 42.1$ \\
\hline ERI $(\mu \mathrm{g} /$ week/Hb in $\mathrm{g} / \mathrm{dL})$ & $3.08 \pm 3.64$ & $3.29 \pm 4.70$ \\
\hline Number of patients administered IV iron & $41 \quad(56.9 \%)$ & $18(60.0 \%)$ \\
\hline IV iron dose (mg/4 weeks) & $35.9 \pm 41.1$ & $34.9 \pm 42.1$ \\
\hline
\end{tabular}

HD: hemodialysis, DM: diabetes mellitus, DW: dry weight, HDF: hemodiafiltration, I-HDF: intermittent infusion $\mathrm{HDF}, \mathrm{Q}_{\mathrm{B}}$ : quantity of blood flow, TSAT: transferrin saturation, RBC: red bool cell, $\mathrm{MCH}$ : mean corpuscular hemoglobin, $\mathrm{Hb}$ : hemoglobin, ESA: erythropoiesis stimulating agent, DA: darbepoetin alfa, ERI: erythropoiesis resistance index, IV : intravenous

\section{2. 血清リン值および補正 Ca 值の変化}

全例では, $\mathrm{FC}$ 投与 3 か月後に血清リン值が有意に 低下し, 補正 Ca 值は変化しなかった。また, 代謝性 アシドーシス患者では, 血清リン值の低下傾向がみら れたが有意ではなく, また, 補正 $\mathrm{Ca}$ 值は変化しなかっ た（表 2).

CKD-MBD 診療ガイドライン達成率は, 全例では, ガイドライン基準の補正 $\mathrm{Ca}$ 值 $8.4 \sim 10.0 \mathrm{mg} / \mathrm{dL}$ を用い た場合， FC 投与開始前 $65.3 \%, F C$ 投与 3 か月後 $66.7 \%$ であった。また，代謝性アシドーシス患者では，FC 投 与開始前 $53.3 \%, \mathrm{FC}$ 投与 3 か月後 $70.0 \%$ であった（図 1).な㧍，当院基準の $8.0 \sim 9.5 \mathrm{mg} / \mathrm{dL}$ を用いた場合， $\mathrm{FC}$ 投与開始前 $72.2 \%, \mathrm{FC}$ 投与 3 少月後 $73.6 \%$, 代謝 性アシドーシス患者では, FC 投与開始前 $66.7 \%, \mathrm{FC}$ 投与 3 か月後 $73.3 \%$ であった.

\section{3. 透析前 $\mathrm{pH}$ および重炭酸濃度の変化}

全例では, 透析前 $\mathrm{pH}$ は低下傾向を認め, 重炭酸濃 度は不変であった。一方, 代謝性アシドーシス患者で は，透析前 $\mathrm{pH}$ は不変であったが，重炭酸濃度は有意 に上昇し, 30 例中 19 例が $22 \mathrm{mEq} / \mathrm{L}$ 以上となった(表 2).

\section{TSAT および血清フェリチン值の変化} 全例では, TSAT および血清フェリチン值は有意に
上昇した．血清フェリチン值 $300 \mathrm{ng} / \mathrm{mL}$ を超える症例 はなかった.このうち, 代謝性アシドーシス患者では, TSAT は有意に上昇し, 血清フェリチン值は不変で あった（表 2).

TSAT 20\%未満かつ血清フェリチン值 $100 \mathrm{ng} / \mathrm{mL}$ 未満の絶対的鉄欠乏の患者は, 全例では, $\mathrm{FC}$ 投与開 始前 $65.3 \%$ から 3 か月後 $23.6 \%$ に著減し, TSAT $20 \%$ 以上かつ血清フェリチン值 $100 \mathrm{ng} / \mathrm{mL}$ 未満の患者が $\mathrm{FC}$ 投与開始前 $20.8 \%$ から 3 か月後 $50.0 \%$ に増加した. 代謝性アシドーシス患者では, 絶対的鉄欠乏の患者 は, $\mathrm{FC}$ 投与開始前 $53.3 \%$ から 3 か月後 $16.7 \%$ に著減 し, TSAT $20 \%$ 以上かつ血清フェリチン值 $100 \mathrm{ng} / \mathrm{mL}$ 未満の患者が FC 投与開始前 $33.3 \%$ から 3 か月後 $66.7 \%$ に増加した（図 2).

\section{5. 分血関連指標および ERI の変化}

全例では, $\mathrm{RBC}, \mathrm{MCH}$ および $\mathrm{Hb}$ は有意に上昇し， ERI は有意に低下した。代謝性アシドーシス患者で は, $\mathrm{RBC}$ は不変, $\mathrm{MCH}$ および $\mathrm{Hb}$ は有意に上昇し, ERI の低下傾向がみられた（表 2).

\section{ESA 投与量および静注鉄剤投与量の変化}

全例では, $\mathrm{ESA}$ 投与量は $\mathrm{FC}$ 投与 3 か月後に有意に 減少した。 また, 静注鉄剤の使用患者数掞よび 4 週あ たりの投与量ともに有意に減少した。代謝性アシドー 
表 2 Changes in clinical parameters after FC oral administration for 3 months.

All patients $(\mathrm{n}=72)$

\begin{tabular}{|c|c|c|c|}
\hline & pre & 3 month & $P$ \\
\hline Phosphorus $(\mathrm{mg} / \mathrm{dL})$ & $5.31 \pm 0.99$ & $4.82 \pm 1.11$ & 0.002 \\
\hline Corrected $\mathrm{Ca}(\mathrm{mg} / \mathrm{dL})$ & $8.73 \pm 0.49$ & $8.80 \pm 0.43$ & 0.300 \\
\hline $\mathrm{pH}$ & $7.42 \pm 0.04$ & $7.41 \pm 0.03$ & 0.087 \\
\hline Bicarbonate $(\mathrm{mEq} / \mathrm{L})$ & $22.70 \pm 2.71$ & $22.92 \pm 2.27$ & 0.572 \\
\hline TSAT $(\%)$ & $17.14 \pm 11.31$ & $25.47 \pm 11.08$ & $<0.001$ \\
\hline Ferritin $(\mathrm{ng} / \mathrm{mL})$ & $55.2 \pm 46.8$ & $78.7 \pm 59.5$ & 0.002 \\
\hline $\operatorname{RBC}\left(10^{4} / \mu \mathrm{L}\right)$ & $354.7 \pm 47.7$ & $374.1 \pm 51.0$ & 0.003 \\
\hline $\mathrm{MCH}(\mathrm{pg})$ & $28.85 \pm 2.82$ & $29.99 \pm 2.79$ & $<0.001$ \\
\hline $\mathrm{Hb}(\mathrm{g} / \mathrm{dL})$ & $10.11 \pm 0.92$ & $11.12 \pm 1.05$ & $<0.001$ \\
\hline ERI $(\mu \mathrm{g} /$ week/Hb in $\mathrm{g} / \mathrm{dL})$ & $3.08 \pm 3.64$ & $1.96 \pm 2.31$ & 0.004 \\
\hline \multicolumn{4}{|l|}{ Acidic patients $(\mathrm{n}=30)$} \\
\hline & pre & 3 month & $P$ \\
\hline Phosphorus (mg/dL) & $5.39 \pm 1.00$ & $4.84 \pm 1.29$ & 0.146 \\
\hline Corrected $\mathrm{Ca}(\mathrm{mg} / \mathrm{dL})$ & $8.60 \pm 0.57$ & $8.73 \pm 0.35$ & 0.305 \\
\hline $\mathrm{pH}$ & $7.40 \pm 0.03$ & $7.40 \pm 0.04$ & 0.740 \\
\hline Bicarbonate $(\mathrm{mEq} / \mathrm{L})$ & $20.17 \pm 1.27$ & $22.78 \pm 2.38$ & $<0.001$ \\
\hline TSAT $(\%)$ & $18.81 \pm 13.01$ & $27.46 \pm 11.82$ & 0.008 \\
\hline Ferritin $(\mathrm{ng} / \mathrm{mL})$ & $55.3 \pm 50.4$ & $66.0 \pm 36.1$ & 0.307 \\
\hline $\mathrm{RBC}\left(10^{4} / \mu \mathrm{L}\right)$ & $358.9 \pm 52.2$ & $365.7 \pm 45.6$ & 0.457 \\
\hline $\mathrm{MCH}(\mathrm{pg})$ & $29.05 \pm 2.86$ & $30.65 \pm 2.52$ & $<0.001$ \\
\hline $\mathrm{Hb}(\mathrm{g} / \mathrm{dL})$ & $10.34 \pm 0.93$ & $11.08 \pm 0.99$ & 0.005 \\
\hline ERI $(\mu \mathrm{g} /$ week/Hb in $\mathrm{g} / \mathrm{dL})$ & $3.29 \pm 4.70$ & $2.21 \pm 2.43$ & 0.197 \\
\hline
\end{tabular}

TSAT: transferrin saturation, RBC: red bool cell, $\mathrm{MCH}$ : mean corpuscular hemoglobin, $\mathrm{Hb}$ : hemoglobin, ERI: erythropoiesis resistance index

シス患者では, ESA 投与量は不変であったが，静注鉄 剤は同様に有意に減少した（表 3 ）.

\section{IV. 考 察}

クエン酸は代謝を受けて重炭酸イオンを生成するた め, 本邦ではクエン酸カリウム・クエン酸ナトリウム 水和物配合製剂（製品名：ウラリット $\left.{ }^{\circledR}\right)$ がアシドー シスの改善の目的で使用され，用量依存的な血中クエ ン酸濃度の上昇 ${ }^{5)}$, アシドーシスの改善が報告されて いる ${ }^{6)}$. 酸性尿の改善効果に関する臨床試験では, ウ ラリット ${ }^{\circledR} 3 \mathrm{~g} /$ 日が重曹 $6 \mathrm{~g} /$ 日に相当する結果が得ら れており, ウラリット ${ }^{\circledR} か ゙$ 重曹より吸収率が高いため と説明されている7. $\mathrm{FC}$ はクエン酸第二鉄水和物であ り，1 錠 $250 \mathrm{mg}$ 中に約 $190 \mathrm{mg}$ のクエン酸を含有す る. 実際, Yokoyama らは FC の開発治験において, 保存期腎不全患者 ${ }^{1)}$ ならびに血液透析患者 ${ }^{2)}$ の血清重 炭酸濃度を上昇させることを報告している。

慢性腎不全患者では，腎機能の低下，廃絶によって 酸が血中に溜まり，代謝性アシドーシスがひき起こさ れ，蛋白異化や骨代謝への影響などが懸念される。 Oka らは, 低い透析前重炭酸濃度が冠動脈石灰化の独
立した危険因子であることを報告している ${ }^{8)}$.また， 海外でも, Tentori らが, 約 1.7 万人の血液透析患者を 対象としたDOPPS (dialysis outcomes and practice patterns study）の解析で, 透析前重炭酸濃度が低い ほど全死亡の死亡リスクが高いことを報告してい る ${ }^{9)}$ ささらに, Vashistha らは, Da Vitaグループの約 11 万人の血液透析患者のデータから, 低い透析前重炭 酸濃度は全死亡, 心血管死㧍よび感染症関連死のリス クが高いことを報告している ${ }^{10)}$ したがって，代謝性 アシドーシスを適切に補正することは重要であると考 えられる。透析液にはアルカリ化剂が配合されている が，本邦で用いられている透析液に含まれるアルカリ 化剛の濃度打よび組成はさまざまであり，その中では $\mathrm{CAB}$ が最もアシドーシス補正効果の強い透析液であ ることが日本透析医学会統計調查委員会公募研究 （JRDR1001）にて明らかにされている1).

理想的には，患者の状態に応じたテーラーメード透 析を行うべきであるが, 本邦では CDDS が普及してお り，すべての患者に同一組成の透析液が用いられるた め, 一部のアシドーシスの強い患者では十分な補正が なされていない.「わが国の慢性透析療法の現況」（以 下, JSDT 統計調查) (2007 年 12 月 31 日現在 $)^{11)}$ によ 
All patients (pre)

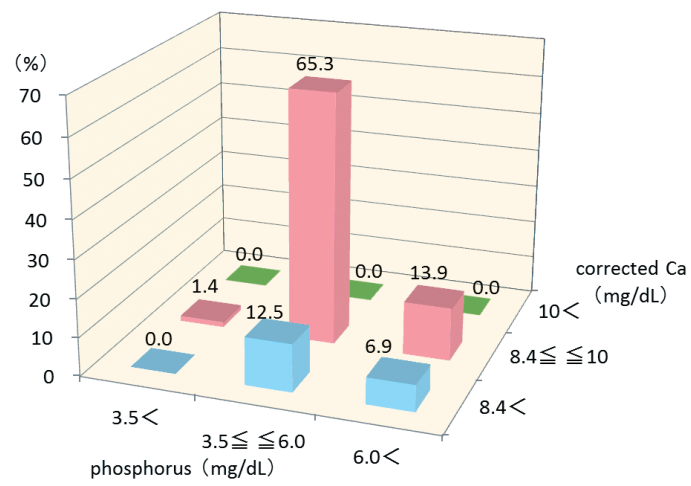

Acidic patients (pre)

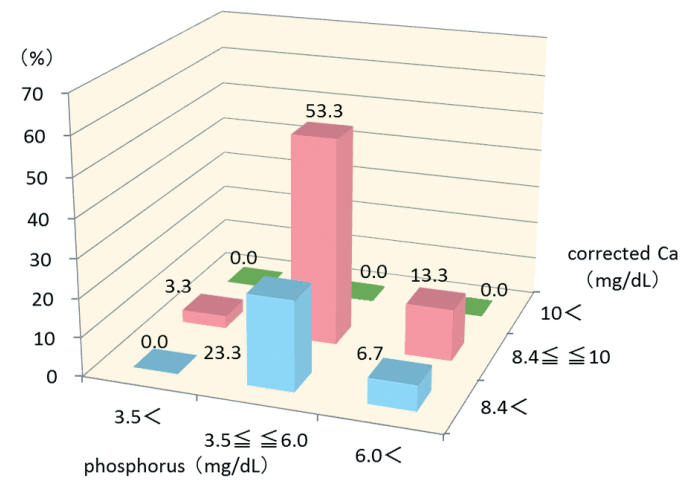

All patients (3 month)

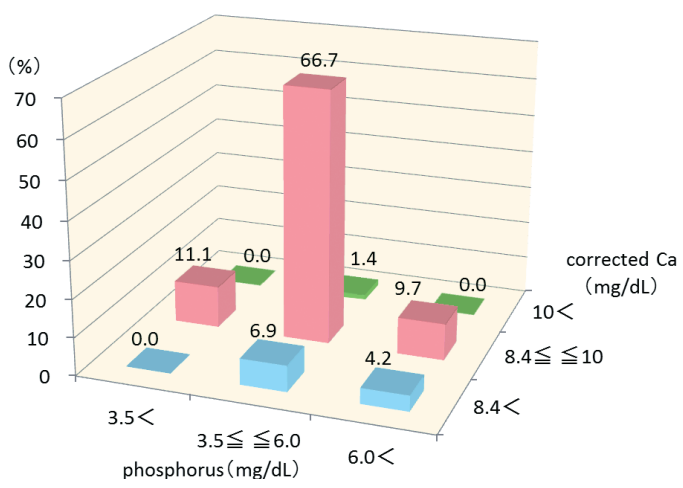

Acidic patients ( 3 month)

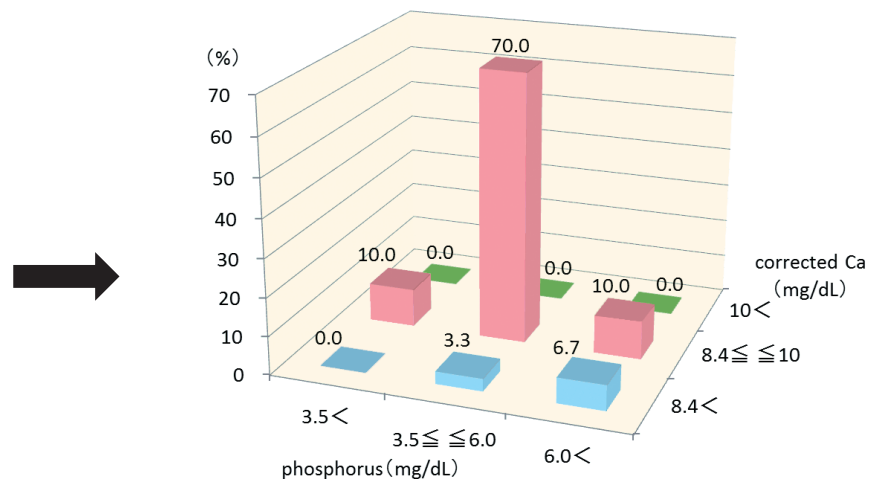

図 1 Changes in achievement rate of both serum phosphorus and corrected Ca concentrations in clinical practice guideline for CKD-MBD after FC oral administration for 3 months.
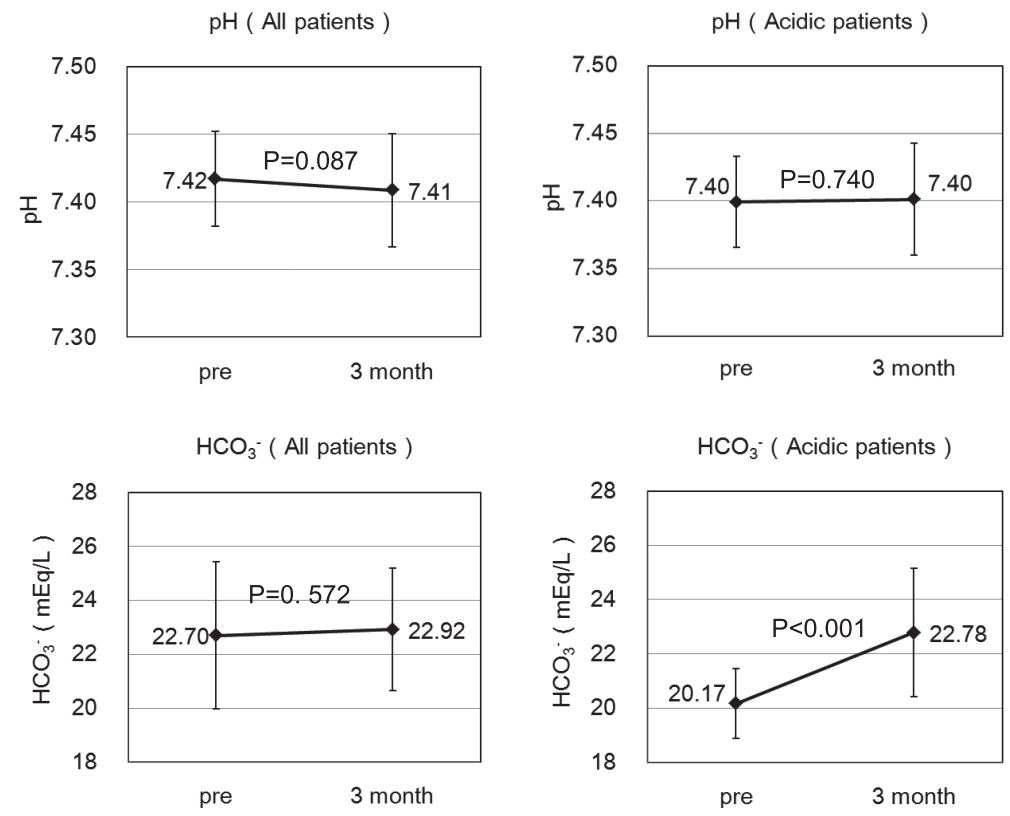

図 2 Changes in $\mathrm{pH}$ and serum bicarbonate concentration after FC oral administration for 3 months.

れば, $22 \mathrm{mEq} / \mathrm{L}$ 未満の施設血液透析患者は約 $68 \%(20$ $\mathrm{mEq} / \mathrm{L}$ 未満では約 $41 \%)$ に及んでいる. 当院では血 液ガス分析は中 1 日の採血で行っているため, 単純に
は比較できないが, アシドーシス補正作用の強い $\mathrm{CAB}$ を用いても, 透析前重炭酸濃度が $22 \mathrm{mEq} / \mathrm{L}$ 未満 の患者が約 $18 \%$ であり, このうち, 本研究の対象患者 
表 3 Changes in ESA dose, number of patients administered IV iron and IV iron dose after FC oral administration for 3 months.

All patients $(n=72)$

\begin{tabular}{lccr}
\hline & pre & 3 month & \multicolumn{1}{c}{$P$} \\
\hline ESA dose $(\mu \mathrm{g} /$ week $)$ & $29.8 \pm 34.1$ & $20.8 \pm 23.1$ & 0.002 \\
Number of patients administered IV iron & $41 / 72(56.9 \%)$ & $26 / 72(36.1 \%)$ & 0.019 \\
IV iron dose $(\mathrm{mg} / 4$ weeks) & $35.9 \pm 41.1$ & $19.8 \pm 31.1$ & $<0.001$ \\
\hline & & & \\
Acidic patients $(\mathrm{n}=30)$ & pre & 3 month & $P$ \\
\hline & $32.9 \pm 45.2$ & $23.4 \pm 24.1$ & 0.232 \\
\hline ESA dose $(\mu \mathrm{g} /$ week $)$ & $18 / 30(60.0 \%)$ & $9 / 30(30.0 \%)$ & 0.037 \\
Number of patients administered IV iron & $34.9 \pm 42.1$ & $17.0 \pm 35.1$ & 0.015 \\
IV iron dose $(\mathrm{mg} / 4$ weeks $)$ & & &
\end{tabular}

ESA : erythropoiesis stimulating agents, IV: intravenous, FC: ferric citrate

72 例中 30 例 $(42 \%)$ が $22 \mathrm{mEq} / \mathrm{L}$ 未満であった。週 初めの中 2 日であれば, さらに透析前重炭酸濃度が低 いであろうことを踏まえれば，特にアシドーシスの強 い患者において透析前重炭酸濃度をより高める必要が あると考えられた

本研究は，当院における FC 使用実態を調查した後 ろ向きの観察研究であり，アシドーシス補正を目的と した FC 投与を行ったわけではないが，結果として透 析前重炭酸濃度 $22 \mathrm{mEq} / \mathrm{L}$ 未満の患者では, $\mathrm{FC}$ 投与 3 か月後の検査で有意な上昇がみられ，30 例中 19 例で $22 \mathrm{mEq} / \mathrm{L}$ 以上（平均值 $22.78 \mathrm{mEq} / \mathrm{L}$ ) となった。こ のとき, $\mathrm{pH}$ の上昇はみられず全例ではむしろ低下傾 向を認めた. JSDT 統計調査 (2009 年 12 月 31 日現在) では，透析前 $\mathrm{pH} 7.45$ 以上では 7.35〜 7.40（対照）に比 して有意に生命予後不良であることが報告された。一 方, Yamamoto らは, 同じデータベースを用いた解析 で，透析前 $\mathrm{pH} 7.40$ 以上は全死亡，心血管疾患による 死亡の独立した危険因子であると報告したが12), $\mathrm{pH}$ 7.40 以上での層別は JSDT 統計調査における $\mathrm{pH} 7.45$ 以上の影響を強く受けている可能性が示唆される。い ずれにしても，これらは観察研究であり，介入によっ て $\mathrm{pH}$ が高くなった場合については明らかではない が，本研究において透析前重炭酸濃度が上昇しても $\mathrm{pH}$ は上昇しなかったことは好ましい結果であったと 考えられる。また，FCが透析前重炭酸濃度 $22 \mathrm{mEq} /$ $\mathrm{L}$ 以上の患者の重炭酸濃度をさらに上昇させることは なく, 少なくとも今回用いた用量の FCでは過補正に なることはなかった。

なお，透析後重炭酸濃度については測定していない が, 正井らは, 週末の透析前重炭酸濃度は週初めに比 して有意に高いが, 透析後重炭酸濃度は有意差のない こと，また，透析液 $\mathrm{pH}$ を高めに設定すると透析後重
炭酸濃度が高くなることを報告した ${ }^{13)}$ 。このように, 透析後の重炭酸濃度は透析液組成に依存することが明 らかにされていることから，FC投与が透析後の過補 正を助長する懸念はないものと考えられる。

これらのことから, CDDS の課題として，同一組成 の透析液を用いるために認めるアシドーシスが十分に 補正されていない患者において, 特に FCの高い有用 性が期待される。

FC は，投与開始前のリン吸着薬に追加あるいは一 部切替えで, 250 750 mg/日の用量で開始し，期間中 適宜増減した。その結果, 全例では血清リン值が有意 に低下し，また代謝性アシドーシス患者でも同程度の 低下傾向がみられた. CKD-MBD 診療ガイドラインで は, 補正 Ca 值の管理目標值を $8.4 \sim 10.0 \mathrm{mg} / \mathrm{dL}$ として いるが，当院では COSMOS study ${ }^{14)}$ の結果などを考 慮し，8.0〜9.5 mg/dL で管理している。このため, リ ン吸着薬としても主に $\mathrm{Ca}$ 非含有リン吸着薬を処方し ているが, $\mathrm{FC} も \mathrm{Ca}$ 非含有リン吸着薬のひとつである ため, $\mathrm{FC}$ 投与により補正 $\mathrm{Ca}$ 值に変化はなかった.

血清リン值および補正 $\mathrm{Ca}$ 值の両方が管理目標值に 入った達成率は，全例では，ガイドライン基準を用い た場合， $\mathrm{FC}$ 投与 3 か月後 $66.7 \%$ ，当院基準を用いた 場合， $73.6 \%$ であった。このうち，代謝性アシドーシ ス患者では, ガイドライン基準では $70.0 \%$, 当院基準 でも $73.3 \%$ であった。 このように $\mathrm{Ca}$ を上昇させるこ となく，良好なリン管理を達成し得た。

$\mathrm{FC}$ は 1 錠 $250 \mathrm{mg}$ 中に 3 価の鉄を約 $60 \mathrm{mg}$ 含有する ため，FC 投与に伴い，TSAT は有意に高くなり，血 清フェリチン值も全例では有意に増加した。TSAT $20 \%$ 未満かつ血清フェリチン值 $100 \mathrm{ng} / \mathrm{mL}$ 未満の絶 対的鉄欠乏患者の割合は，全例では，FC 投与開始前 65.3\%から 23.6\%に著減し, TSAT 20\%以上かつ血清 

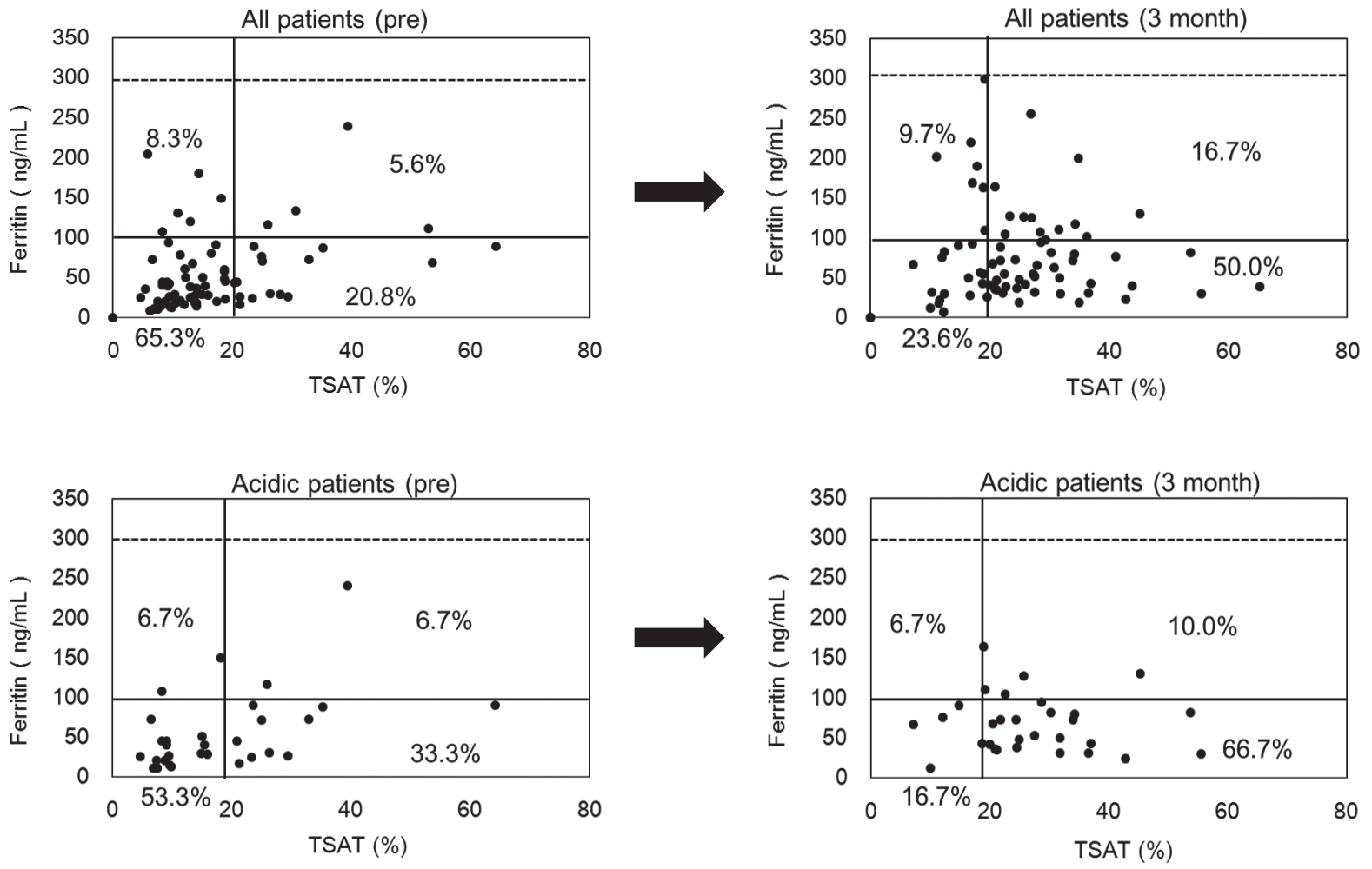

図 3 Changes in distribution of TSAT and serum ferritin concentration after FC oral administration for 3 months.

フェリチン值 $100 \mathrm{ng} / \mathrm{mL}$ 未満の患者が $\mathrm{FC}$ 投与開始前 20.8\%から 50.0\%に増加した. 血清フェリチン值が 300 $\mathrm{ng} / \mathrm{mL}$ を超える患者はなかった。代謝性アシドーシ ス患者に限っても同様であった，当院では，これまで 鉄補充には慎重であったが，その結果として 6 割以上 もの患者が絶対的鉄欠乏であったことが明らかとな り，適切な鉄補充について見直す機会となった．FCは 鉄補充を目的とした医薬品ではないが，鉄を含有する 以上，鉄をみながらリンをコントロールすることが必 要である. 今回，FCを投与した多くの患者で鉄欠乏 状態の改善がみられ, TSAT $20 \%$ 以上かつ血清フェリ チン值 $100 \mathrm{ng} / \mathrm{mL}$ 未満の患者が著しく増加し, FC 由 来の鉄が効率良く利用されていることが示唆された.

しかしながら，FCを投与しても未だ絶対的鉄欠乏患 者が $23.6 \%$ 存在し, TSAT $20 \%$ 未満の患者は $33.3 \%$ 存 在したことから, 今後, 併用するリン吸着薬の比率を 見直しつつ，FCの増量を考慮すべきと考えられた。

$\mathrm{FC}$ 投与により $\mathrm{Hb}$ が上昇し，それに伴い ESA 投与 量が減少した。 これは主として FCの構成成分である 鉄が吸収された結果と考えられるが, $\mathrm{MCH}$ 上昇のみ ならず，興味深いことに ESA 投与量減少にもかかわ らず, $\mathrm{RBC}$ が有意に増加した．鉄が赤芽球の分化，脱 核にも関わっていることが指摘されており ${ }^{15)}$, ERI 低 下は FC 由来の鉄が $\mathrm{Hb}$ 合成のみならず， $\mathrm{RBC}$ 増加に も一部寄与している可能性が示唆された.
また, Diskin らは鉄欠乏のない血液透析患者におい て，ESA 投与量に関連する有意な独立した因子とし て, 血清リン值と正の相関, 血清重炭酸濃度と負の相 関があることを報告している ${ }^{16)}$. 本研究において, FC 投与により鉄吸収および血清リン值低下，さらに代謝 性アシドーシスの患者では透析前重炭酸濃度上昇が認 められたことから，これらの作用が相俟って ESA 投 与量が減少した可能性がある.

FC 投与により鉄が吸収された結果, 従来, 鉄補充 の目的で使用していた静注鉄剤の処方患者数が有意に 減少し，投与量も有意に減少した。静注鉄剤は経口鉄 剂に比して心血管イベント発症, 感染症による入院の リスクが高いとの REVOKE Trial での報告 ${ }^{17)}$, 静注で の鉄剤投与は経口鉄剤より感染症のリスクが上昇する との systematic review ${ }^{18)}$ がある。また, 静注鉄剤は副 作用予防の観点から， 2 分以上かけでゆっくり投与し なければならないとされている。一般に静注鉄剤は透 析終了時に投与されることが多いが, 透析装置の操作 を含む他の業務で多忙なため, 当院では透析終了時の 投与を透析中の投与に変更し, スタッフ業務の軽減を 図っている。しかし, 静注鉄剤はプレフィルドシリン ジ化されていないため, 調製の手間を要し, アンプル カットに伴う微小なガラス片の混入や怪我のリスクも あり，スタッフの負担となっている。一方，経口鉄剤 は, しばしば悪心・嘔吐などの消化器症状を呈し, 服 
薬順守の課題がある。しかし，FC は悪心・嘔吐の消 化器症状はほとんどみられず，また，リン吸着薬とし て服用すれば，別途経口鉄剤を服用する必要もない。 さらに静注鉄剤の投与も不要あるいは減少することか ら, 患者, スタッフの双方にメリットがあるといえる.

なお, $\mathrm{FC}$ 投与 3 か月後の DA 換算の ESA 投与量は $20.8 \mu \mathrm{g} /$ 週（全例平均）であり，当院の鉄欠乏のない 患者における投与量に比して多い傾向であった. Hamano らの報告では, DAの反応性が最も良い TSATおよびフェリチン值は，それぞれ30～40\%およ び 100〜200 ng/mL 程度であった ${ }^{19)}$. 本研究の FC 投 与量下では一部の患者では未だ鉄が充足されておら ず, ESAに依存した貧血管理が行われている可能性が ある.日本透析医学会2015年版 慢性腎臓病患者にお ける腎性貧血治療のガイドライン ${ }^{20)} に$ 沿った適切な管 理を目指し， FC投与量を設定するべきと考えられた。

$\mathrm{FC}$ 投与により $\mathrm{ESA}$ 投与量の削減を含む総薬剤費削 減効果は約 3,200 円/患者/月（年間約 4 万円） と試算 された．未だ絶対的鉄欠乏の患者が存在することを踏 まえれば,さらなる削減が可能と推測される.ただし, ESA 削減が可能であった患者は, 鉄欠乏のある患者で 顕著であり，ESA 投与量を削減するために漫然と鉄を 補充することを目指すべきではない.あくまでも ESA と鉄をバランス良く投与することが重要と考えられる.

\section{結 論}

FCは,リン吸着および鉄補充に伴う貧血改善作用 に加え，代謝性アシドーシス補正作用を有し，特に異 所性石灰化等のリスクとなる代謝性アシドーシスを有 する血液透析患者において有用なリン吸着薬になり得 る.

利益相反 : 申告すべき利益相反はなし.

\section{文献}

1）山本忠司，伊達敏行．血液透析液・補充液. 腎と透析 2014；増刊号：176-80.

2) Yokoyama K, Hirakata H, Akiba T, et al. Ferric citrate hydrate for the treatment of hyperphosphatemia in nondialysis-dependent CKD. Clin J Am Soc Nephrol 2014; 9: 543-52.

3) Yokoyama K, Akiba T, Fukagawa M, et al. A randomized trial of JTT-751 versus sevelamer hydrochloride in patients on hemodialysis. Nephrol Dial Transplant 2014；29: 1053-60.

4）日本透析医学会. 慢性腎臓病に伴う骨・ミネラル代謝
異常の診療ガイドライン. 透析会誌 2012；45：301-56.

5）小川由英, 宇治康明. CG-120 投与の健常人に及ぼす 影響一単回投与試験一. 薬理と治療 1986；14：525172.

6）松田一郎, 田中恒男, 北川照男, 他. 腎尿細管性アシ ドーシスに対する CG-120 の臨床評価一重曹とのクロ スオーバー試験成績一 . 小児科臨床 1986；39：225766.

7）上田泰, 御巫清允, 熊谷朗, 他, 尿アルカリ化剂 $\mathrm{CG}^{-}$ 120 （ウラリット-U）の臨床評価一重曹を対照とした 多施設の非盲検 well controlled trial一. 臨床評価 1981；9: 421-33.

8) Oka M, Ohtake T, Mochida Y, et al. Correlation of coronary artery calcification with pre-hemodialysis bicarbonate levels in patients on hemodialysis. Ther Apher Dial 2012; 16: 267-71.

9) Tentori F, Karaboyas A, Robinson BM, et al. Association of dialysate bicarbonate concentration with mortality in the dialysis ouncomes and practice patterns study (DOPPS). Am J Kidney Dis 2013; 62: 738-46.

10) Vashistha T, Kalantar-Zadeh K, Molnar MZ, Torlén K, Mehrotra R. Dialysis modality and correction of uremic metabolic acidosis: Relationship with allcause and cause-specific mortality. Clin J Am Nephrol 2013； 8: 254-64.

11）日本透析医学会統計調査委員会. わが国の慢性透析療 法の現況 (2007 年 12 月 31 日現在). 東京：日本透析 医学会, 2008.

12) Yamamoto T, Shoji S, Yamakawa $T$, et al. Predialysis and Postdialysis pH and Bicarbonate and Risk of AllCause and Cardiovascular Mortality in Long-term Hemodialysis Patients. Am J Kidney Dis 2015; 66: 469-78.

13）正井基之, 坂井健彦, 内野順司, 他. カーボスター透 析液の調整と慢性維持透析患者の酸塩基平衡. 透析会 誌 2013； 46：651-9.

14) Fernández-Martín JL, Martínez-Camblor P, Dionisi MP, et al. Improvement of mineral and bone metabolism markers is associated with better survival in haemodialysis patients: the COSMOS study. Nephrol Dial Transplant 2015; 30: 1542-51.

15) Byrnes C, Lee YT, Meier ER, et al. Iron dose-dependent differentiation and enucleation of human erythroblasts in serum-free medium. J Tissue Eng Regen Med 2016; 10: E84-9.

16) Diskin CJ, Stokes TJ, Dansby LM, Radcliff L, Carter TB. Can acidosis and hyperphosphataemia result in increased erythropoietin dosing in haemodialysis patients? Nephrology 2006; 11: 394-9.

17) Agarwal R, Kusek JW, Pappas MK. A randomized trial of intravenous and oral iron in chronic kidney disease. Kidney Int 2015； 88: 905-14.

18) Litton E, Xiao J, Ho KM. Safety and efficacy of intra- 
venous iron therapy in reducing requirement for allogeneic blood transfusion: systematic review and meta-analysis of randomised clinical trials. BMJ 2013; 15: 347: f4822.

19) Hamano T, Fujii N, Hayashi T, Yamamoto H, Iseki K, Tsubakihara Y. Thresholds of iron markers for iron deficiency erythropoiesis-finding of the Japanese nationwide dialysis registry. Kidney Int Suppl 2015; 5: 23-32.

20）日本透析医学会. 2015 年版 慢性腎臟病患者における 腎性貧血治療のガイドライン．透析会誌 2016；49： 89-158. 